\title{
List of translations
}

\author{
Adi Granth \\ the 'first book'; the Sikh scriptures \\ Adivasi \\ ahimsa \\ 'original inhabitants', tribal groups, aboriginals \\ andolan \\ non-violence \\ Arthashastra \\ Bhagavadgita \\ movement \\ 'Science of Material Gain': written around 250 AD, \\ dealing with the nature, politics and economy of \\ the ancient Indian state \\ religious and philosophical Sanskrit poem, dating \\ from around $300 \mathrm{BC}$ and forming an episode in the \\ sixth book of the Mahabharata; it is one of the two \\ great Hindu epics, and the supreme religious work \\ of Hinduism \\ bhakti \\ devotion to God \\ Bharata \\ bharatnatyam \\ the foremost Aryan tribe \\ classical Indian dance form of south India \\ boxwallahs \\ urban salaried employees \\ Brahmins \\ the first, highest caste, the priests \\ buniya \\ crore \\ a trading class \\ Dalit \\ dasas \\ devadasi \\ dharma \\ dharma chakra \\ dhimmis \\ dhoti-kurta \\ 10 million units, e.g of money/people \\ the lowest castes/untouchables \\ slaves \\ temple dancer-prostitute \\ religion, also duty, responsibility and law \\ 'wheel of the law' \\ protected peoples \\ traditional Indian dress for men \\ dirigisme \\ diwan \\ economic control by the state \\ minister of revenue \\ diwani \\ revenue
}




\begin{tabular}{|c|c|}
\hline Doordarshan & Indian television channel \\
\hline 'garibi hatao' & 'remove poverty' \\
\hline Harijans & $\begin{array}{l}\text { literally 'god's people'; name given to untouchables } \\
\text { by Gandhi }\end{array}$ \\
\hline homa & oblation; often of burnt ghee \\
\hline jajmani & $\begin{array}{l}\text { social system in which landlords look after locals in } \\
\text { return for their services }\end{array}$ \\
\hline Jana gana mana & the Indian national anthem \\
\hline janambhoomi & birthplace \\
\hline janapads & district, also an ancient Hindu popular assembly \\
\hline jatis & subcastes \\
\hline jihad & holy war \\
\hline jiva & soul \\
\hline jizya & a tax imposed on non-Muslims by Muslim rulers \\
\hline kachcha & short cotton underwear (one of the Sikh five Ks) \\
\hline kangha & comb (one of the Sikh five Ks) \\
\hline kar sevaks & Hindu holy workers \\
\hline kara & steel bracelet (one of the Sikh $5 \mathrm{Ks}$ ) \\
\hline Kautilya & $\begin{array}{l}\text { prime minister of Chandragupta Maurya and author } \\
\text { of the Arthashastra }\end{array}$ \\
\hline kes & long hair (one of the Sikh five Ks) \\
\hline khadi & cloth woven by hand using handspun yarn \\
\hline khalsa & pure \\
\hline kirpan & sword (one of the Sikh five Ks) \\
\hline Kshatriyas & the second caste, the warriors \\
\hline lakh & 100,000 units, e.g. of money/population \\
\hline Lok Sabha & the lower house of the Indian parliament \\
\hline lok sevak & servant of the people \\
\hline Maharajadhiraja & Great King of Kings \\
\hline malik & noble \\
\hline mandala & circle \\
\hline mansabdars & $\begin{array}{l}\text { office holders ranked on the number of cavalry they } \\
\text { maintained }\end{array}$ \\
\hline maquiladoras & export processing zones \\
\hline moksha & $\begin{array}{l}\text { salvation, nirvana, freedom from the cycle of life } \\
\text { and death }\end{array}$ \\
\hline muhtasibs & censors of public morals \\
\hline neem & $\begin{array}{l}\text { the leaves and bitter bark of the Azadirachta Indica } \\
\text { tree, used medicinally }\end{array}$ \\
\hline nishka & an early measure of value, and later a gold coin \\
\hline pahul & Sikh baptism ceremony \\
\hline panchayat & village council \\
\hline
\end{tabular}




\begin{tabular}{|c|c|}
\hline Panchsheel & $\begin{array}{l}\text { five principles incorporated into a treaty between } \\
\text { India and China over Tibet in } 1954\end{array}$ \\
\hline paura & ancient Hindu popular assembly \\
\hline pravasis & overseas Indians \\
\hline puranas & old Hindu stories \\
\hline raja & king \\
\hline Rajput & Hindu warrior prince of Rajasthan \\
\hline Rajya Sabha & the upper house of the Indian parliament \\
\hline Rath Yatra & $\begin{array}{l}\text { Hindu religious procession; a rath is a temple on } \\
\text { wheels }\end{array}$ \\
\hline Rig Veda & $\begin{array}{l}\text { the earliest of the four Vedas, or sacred books of the } \\
\text { Indo-Aryans, and the oldest scripture in the world }\end{array}$ \\
\hline sangam & academy or college \\
\hline sansad & parliament \\
\hline Satavahana & an ancient Indian dynasty \\
\hline satyagraha & $\begin{array}{l}\text { a form of spiritual passive resistance (satya - truth; } \\
\text { agraha - to hold) }\end{array}$ \\
\hline shreni & artisan and merchant guilds \\
\hline Shudras & the fourth caste, the labourers \\
\hline Sri Guru Granth Sahib & Sikh sacred text \\
\hline stupa & Buddhist monument \\
\hline swadeshi & indigenous, e.g. goods made in India \\
\hline swarajya & self-government \\
\hline Vaishyas & the third caste, the commons, traders \\
\hline varna & colour \\
\hline varnashram & the Hindu caste system \\
\hline vasudhaiva kutumbkum & the fundamental unity of all humanity \\
\hline Veda/vedic & derived from vid, the holy books of the Aryans \\
\hline vid & to know \\
\hline videshi & foreign \\
\hline zamindar & a landowner paying land tax \\
\hline
\end{tabular}


Sagarika Dutt - 9781847792143 Downloaded from manchesterhive.com at $04 / 26 / 2023$ 11:28:24AM via free access 